\title{
REVIEW
}

\section{Appetite regulation and weight control: the role of gut hormones}

\author{
B Perry ${ }^{1,2}$ and $Y$ Wang $^{1,2}$
}

The overwhelming increase in the prevalence of overweight and obesity in recent years represents one of the greatest threats to the health of the developed world. Among current treatments, however, gastrointestinal (GI) surgery remains the only approach capable of achieving significant weight loss results with long-term sustainability. As the obesity prevalence approaches epidemic proportions, the necessity to unravel the mechanisms regulating appetite control has garnered significant attention. It is well known that physical activity and food intake regulation are the two most important factors involved in body weight control. To regulate food intake, the brain must alter appetite. With this realization has come increased efforts to understand the intricate interplay between gut hormones and the central nervous system, and the role of these peptides in food intake regulation through appetite modulation. This review discusses the central mechanisms involved in body weight regulation and explores a suite of well characterized and intensely investigated anorexigenic and orexigenic gut hormones. Their appetite-regulating capabilities, post-Gl surgery physiology and emerging potential as anti-obesity therapeutics are then reviewed.

Nutrition and Diabetes (2012) 2, e26; doi:10.1038/nutd.2011.21; published online 16 January 2012

Keywords: obesity; appetite; hypothalamus; gut hormones

\section{INTRODUCTION}

The overwhelming increase in the prevalence of overweight and obesity in recent years represents one of the greatest threats to the health of the developed world. ${ }^{1}$ Aside from the associated increases in morbidity and mortality, the personal, societal and devastating economic consequences have been well documented. ${ }^{2}$ Even modest weight loss achieved through currently used approaches can dramatically reduce these consequences, yet gastrointestinal (Gl) surgery remains the only treatment offering sustainable weight loss results. Noteworthy, these results have, in part, been linked to alterations in the physiology of circulating gut hormones and their appetite-regulating capabilities. ${ }^{3}$ In tandem with the realization of the devastating global obesity epidemic and its related co-morbidities over the last few decades, is the increasing recognition and understanding of the intricate interplay between gut hormones and the central nervous system (CNS) ${ }_{1}^{4}$ and the regulation of food intake through appetite modulation. ${ }^{5}$ Several of these circulating appetite modulators, including ghrelin, the only known orexigenic gut hormone, ${ }^{6}$ and a suite of anorexigenic gut hormones, including cholecystokinin (CCK), pancreatic polypeptide (PP), peptide YY (PYY), glucagon-like peptide (GLP)-1, and oxyntomodulin (OXM), have been shown to influence appetite in humans. ${ }^{7}$ As a result, there has been increasing momentum aimed at turning this evidence-based knowledge into practical anti-obesity intervention. With all of the current approaches exhibiting problems, ${ }^{3}$ and none, except for Gl surgery demonstrating long-term efficacy, ${ }^{8}$ post-Gl surgery gut hormone physiology and gut hormone administration or co-administration may provide vital insight and prove to be useful targets in the ongoing quest for safe and effective antiobesity therapies or treatments.

\section{CENTRAL MECHANISMS IN BODY WEIGHT REGULATION}

In the CNS, the hypothalamus is the key region involved in the regulation of appetite. ${ }^{1}$ It had previously been hypothesized that satiety was controlled by the ventromedial hypothalamic nucleus, and that feeding was controlled by the lateral region. ${ }^{9}$ This early hypothesis has, however, evolved into a much more comprehensive and complex understanding of the integrated neural network responsible for the regulation of appetite, involving discrete pathways within specific nuclei of the hypothalamus, ${ }^{1}$ and various regulatory modulators. ${ }^{10}$ The regulation of feeding, energy intake and expenditure, and body weight is a homeostatic process. ${ }^{11}$ Information regarding general health is communicated predominantly via long-term humoral signals, whereas meal initiation and termination are believed to be regulated via short-term signals, such as neural signals from the brain and humoral signals from the gut. $^{12}$ The receipt and integration of these signals occur mainly in the hypothalamus, and are largely regulated by the hypothalamic arcuate nucleus (ARC), located at the base of the region. ${ }^{1}$ Gut hormone receptors are located on neuronal populations within the $\mathrm{ARC}^{3}$ which is also partially accessible to circulating appetite modulators due to its incomplete isolation from the blood-brain barrier (BBB). ${ }^{1}$ Within the ARC, there exists two distinct populations of neurons responsible for appetite regulation; the proopiomelanocortin (POMC) appetite-inhibiting neurons and the neuropeptide $Y$ (NPY) and agouti-related peptide (AgRP) appetitestimulating co-expressing neurons. ${ }^{13,14}$ Signals from the periphery result in changes in the relative activity of these two neuronal sub-populations and the release of their respective neuropeptides, subsequently influencing feeding behavior and energy expenditure. $^{15}$

\footnotetext{
${ }^{1}$ Institute for Nutrisciences and Health, National Research Council Canada, Charlottetown, Prince Edward Island, Canada and ${ }^{2}$ Department of Biomedical Sciences, University of Prince Edward Island, Charlottetown, Prince Edward Island, Canada. Correspondence: Dr Y Wang, Institute for Nutrisciences and Health, National Research Council Canada, Charlottetown, Prince Edward Island, Canada C1A 4 P3. 


\section{LONG-TERM ADIPOSITY SIGNALS}

Leptin

Early propositions surrounding the regulation of body weight implicated body fat content as a key player in a so-called adipostat mechanism, ${ }^{16}$ which hypothesized the presence of an unknown circulating factor capable of relaying information to the hypothalamus. Several factors were subsequently proposed, but inconclusively proven, until the revolutionary discovery of leptin in $1994 .{ }^{17}$ Expressed and secreted exclusively by white adipose tissue adipocytes, the circulating levels of leptin are proportional to fat mass. ${ }^{1}$ Either peripheral or central administration of leptin has been demonstrated to reduce food intake and body weight and increase energy expenditure in rodents, ${ }^{18}$ and activation of hypothalamic neurons expressing the leptin receptor has suggested the mediation of its effects via this central region. ${ }^{1}$ Furthermore, leptin has been shown to inhibit the orexigenic NPY/AgRP co-expressing neurons, and to stimulate the anorexigenic POMC-expressing neurons, within the hypothalamic ARC. ${ }^{19}$ Leptin represents one of the core components of the physiological system that controls body weight in mammals. Humans with leptin deficiency are obese, ${ }^{20}$ and decreased leptin production from white adipose tissue has been demonstrated to contribute to a plethora of metabolic abnormalities associated with visceral obesity. ${ }^{21}$ A study in obese men demonstrated that circulating leptin levels adjusted for body fat were inversely correlated with body weight, suggestive of a leptin deficient state associated with obesity. ${ }^{21}$ Therapies using leptin or leptin agonists may, therefore, prove to be useful future tools against obesity-related metabolic disturbances, and therapy involving leptin replacement has to date been shown to result in significant weight loss. ${ }^{22}$ Obesity, however, is also often associated with increased circulating leptin levels. ${ }^{23}$ This, combined with the lack of expected corresponding leptin-mediated effects, has given rise to the concept of leptin resistance. ${ }^{24}$ In many of these cases, despite high circulating levels and the presence of functional receptors, the expected anorexigenic effects of leptin are significantly diminished. ${ }^{25}$ Receptor overstimulation, and thus activation of negative feedback loops that serve to block leptin signaling, has been proposed as a possible contributing factor to the development of leptin resistance. ${ }^{26}$ In diet-induced obese mice, the ability to reduce food intake and thus body weight in response to peripheral leptin treatment has been demonstrated. ${ }^{26}$ In the same model, resistance has been shown to eventually develop to even centrally-administered leptin treatment, ${ }^{27}$ and leptin-responsive neurons become incapable of activating downstream signaling pathways of the leptin receptor. ${ }^{26}$ Studies in obese rodents have also revealed an impairment of leptin transport across the BBB as being closely associated with leptin resistance. ${ }^{25}$ This latter concept has given rise to an alternative explanation wherein restrictive entry of leptin across the BBB results in leptin insufficiency at its central target sites, and perhaps an attenuation in the leptin signaling cascade. $^{28}$

Insulin

As an adiposity signal, insulin is believed to have a similar lipostatic role to that of leptin, although its central effects on food intake and energy homeostasis are less efficient. ${ }^{29}$ Similar to leptin, circulating insulin levels are proportional to the degree of adiposity. ${ }^{30}$ Central administration of insulin in rodents has been shown to reduce food intake and body weight, ${ }^{31}$ and in the ARC, insulin is thought to function through inhibition of NPY/AgRP co-expressing neurons. ${ }^{10}$ In addition to sharing some of the appetite-regulating and lipostatic capabilities to that of leptin, insulin is furthermore known to stimulate the synthesis and secretion of leptin from white adipose tissue through a feedback loop referred to as the adipo-insular axis. ${ }^{32}$ There are some common hypothalamic targets of leptin and insulin, and evidence of common signal transduction pathways also suggests crosstalk between the two hormones. ${ }^{33}$ As with leptin, increased adiposity can lead to a decrease in insulin sensitivity and a state of insulin resistance. ${ }^{34}$ Further to this traditional understanding of the consequence of adiposity on insulin and its lipostatic effects, it is also believed that adiposity might in fact be a consequence of insulin resistance itself. ${ }^{35}$ With the recognition and identification of insulin resistance as a potential underlying cause of various metabolic abnormalities, particularly including obesity, ${ }^{36}$ has come increased investigation aimed at elucidating potential insulin-sensitizing agents. Approaches aimed at improving insulin sensitivity by way of pharmacological intervention remain a driving force in drug development. ${ }^{37}$ One such drug, metformin, suppresses hepatic glucose production ${ }^{38}$ and has been shown to improve insulin sensitivity in humans. ${ }^{39}$ Beneficial weightstabilizing or weight-loss effects of this widely-used drug of choice in clinical practice have also been documented in both diabetic and non-diabetic adults, ${ }^{40,41}$ adolescents ${ }^{42}$ and children. ${ }^{43}$ More recently, however, certain data have challenged the safety of these pharmacological approaches. ${ }^{44}$ Alternative approaches, in particular those involving plant-based medicinal compounds, have, therefore, been intensely investigated for their potential insulin-sensitizing capabilities. Berberine chloride has been shown to function as an insulin-sensitizing natural product in diabetic rats, ${ }^{45}$ and an alcoholic extract of Artemisia dracunculus has shown promising results in primary human skeletal muscle culture. ${ }^{37}$ Insulin receptors have been identified in central areas linked to food intake regulation, ${ }^{46}$ and it is well established that, in addition to sufficient supply of insulin to the brain, insulin receptor function is vital for energy homeostasis. As with the recently increasing investigation focused on the discovery of insulin-sensitizing agents, products aimed at improving insulin receptor function have also been targeted. Natural products, such as the traditional Chinese medicine Gynostemma pentaphyllum, have been shown to improve glucose tolerance through enhancement of insulin receptor sensitivity in obese diabetic rats, ${ }^{47}$ leading to the initiation of human clinical trials. Future research will undoubtedly further elucidate safe and effective natural products as potential insulin- and/or insulin receptor-sensitizers, but there remains a wealth of work to be done in order to unveil the mechanisms of these products.

\section{GUT HORMONES AND OBESITY}

The $\mathrm{Gl}$ tract is the largest endocrine organ in the body and is believed to have an important appetite-regulating role as a source of various regulatory peptide hormones. ${ }^{5,15}$ Post-prandial satiety is believed to be regulated by a sensory system that communicates between the gut and appetite-regulating centers in the brain, with the hypothalamus being responsible for nutrient and energy sensing and corresponding adjustments in food intake. ${ }^{1}$ In the gut, there exists a suite of endocrine cells, which synthesize and release various hormones in response to nutrient and energy intake, ${ }^{1}$ and it has been demonstrated that these hormones influence appetite in humans and rodents when administered at physiological levels ${ }^{7,48}$ (Table 1). Distinguishing between genuine satiating effects and reductions in appetite due to nausea or feelings of ill-health can potentially confound experimental results. Food intake is influenced not only by nutritional status but also by various palatability cues, including taste and smell. ${ }^{49,50}$ Dose administration by way of oral gavage can be used to mitigate potential aversion to taste and/or smell and effectively allow for a more critical analysis of the outcomes of such studies. Collectively, unlike leptin and insulin, which have been proposed to signal long-term energy status, gut hormones are thought to have a critical role in meal initiation and termination. ${ }^{51,52}$ 
Table 1. Peripheral effects of selected food intake-regulating gut hormones

\begin{tabular}{llcc}
\hline Gut hormone & Site of synthesis & $\begin{array}{c}\text { Food intake- } \\
\text { regulating } \\
\text { receptor }\end{array}$ & $\begin{array}{c}\text { Peripheral } \\
\text { effect on } \\
\text { food intake }\end{array}$ \\
\hline CCK & Intestinal L-cells & CCK $_{\text {A }}$ & Decrease \\
Ghrelin & Stomach & GHS & Increase \\
PP & Pancreas/colon & Y4R & Decrease \\
PYY & Intestinal L-cells & Y2R & Decrease \\
GLP-1 & Intestinal L-cells & GLP1R & Decrease \\
OXM & Intestinal L-cells & GLP1R? & Decrease \\
\hline
\end{tabular}

Abbreviations: $\mathrm{CCK}$, cholecystokinin; $\mathrm{CCK}_{\mathrm{A}}$, cholecystokinin receptor subtype $A$; GHS, growth hormone secretagogue receptor; GLP-1, glucagon-like peptide-1; GLP1R, GLP-1 receptor; OXM, oxyntomodulin PP, pancreatic polypeptide; PYY, peptide YY; Y2R, PYY Y2 receptor; Y4R, PP Y4 receptor.

\section{Cholecystokinin}

CCK, the first gut hormone reported to affect appetite, ${ }^{53}$ has been shown to dose-dependently reduce food intake in both rats ${ }^{53}$ and humans, ${ }^{54}$ and in response to meal initiation, plasma levels have been reported to rise within 15 min. ${ }^{55}$ Within the GI tract, CCK is predominantly synthesized and released from the duodenum and jejunum, ${ }^{56}$ where its local regulatory effects include stimulation of gallbladder contraction and inhibition of gastric emptying. ${ }^{57}$ In addition to its $\mathrm{Gl}$ tract distribution, CCK is also widely distributed within the hypothalamus, predominantly in the median eminence and ventromedial nucleus, and represents the most abundant neuropeptide in the CNS. ${ }^{58}$ Centrally-administered CCK has been shown to reduce food intake in rodents, ${ }^{59}$ whereas peripheral administration has been shown to reduce food intake in both rodents and humans, through a reduction in meal size and duration. ${ }^{60}$ As a result, CCK has been investigated as a potential therapeutic target for the management of obesity. ${ }^{5}$ However, compensatory increases in meal frequency, ${ }^{61}$ the development of tolerance following infusion (intraperitoneal), ${ }^{62}$ and the short half-life of the peptide ${ }^{63}$ may undermine the therapeutic utility of CCK. In addition, circulating levels in response to caloric ingestion post-Gl surgery have been reported as unchanged. ${ }^{64}$ Two CCK receptor subtypes have been characterized, including $\mathrm{CCK}_{\mathrm{A}}$ and $\mathrm{CCK}_{\mathrm{B}}$, in the Gl tract and brain, respectively. ${ }^{63}$ Of the two, evidence exists for $\mathrm{CCK}_{A}$ as being the more important regulator of food intake, ${ }^{65}$ and a reversal of the inhibitory effect on food intake following administration of a $\mathrm{CCK}_{\mathrm{A}}$ antagonist in rats, ${ }^{66}$ and increased hunger and meal size in humans, ${ }^{67}$ have been shown. In recent years, the main area of therapeutic interest for $\mathrm{CCK}_{\mathrm{A}}$ receptor agonists has been in obesity treatment. ${ }^{68}$ In $\mathrm{CCK}_{\mathrm{A}}$ receptor knockout rats, there is an elicited increase in meal size and resultant onset obesity, ${ }^{69}$ attributable to over-expression of NPY neurons in the ARC. ${ }^{70}$ The orally-active $\mathrm{CCK}_{\mathrm{A}}$ receptor agonist GI181771X has been shown to safely and effectively inhibit gastric emptying in humans, ${ }^{71}$ yet a 24 week double-blind randomized study in obese subjects showed no net reduction in body weight and no beneficial effects on waist circumference. ${ }^{72}$ Thus, as with the therapeutic utility of CCK administration, $\mathrm{CCK}_{\mathrm{A}}$ receptor monotherapy appears to hold minimal promise as a future antiobesity tool. The majority of research into the potential therapeutic utility of CCK and orally-active CCK receptor ligands has, however, taken place in only the last decade. Additional human trials are required to support and strengthen the existing data revealed through both animal and human studies, and future investigations, perhaps involving co-administration with other gut hormones, may be warranted.

\section{Ghrelin}

The 28-amino acid peptide hormone ghrelin, produced predominantly in the stomach, ${ }^{73}$ represents the only known orexigenic gut hormone identified to date. ${ }^{5}$ Ghrelin binds to the growth hormone secretagogue receptor which is highly expressed in the hypothalamus and brain stem. ${ }^{74}$ Although its signaling mechanisms remain to be completely understood, a particularly important role for the hypothalamic ARC and its NPY/AgRP coexpressing neurons has been suggested. ${ }^{75}$ Expression of the growth hormone secretagogue receptor has been demonstrated in NPY neurons, ${ }^{76}$ and NPY and AgRP antagonists have been shown to abolish ghrelin-induced feeding. Since its discovery in $1999{ }^{73}$ ghrelin has been proposed to function as a meal initiator, in part due to its potent appetite-stimulating effects in freefeeding rats. ${ }^{77}$ Ghrelin has also been shown to stimulate appetite in both lean and obese humans, ${ }^{78,79}$ and infusion (intravenous) in healthy volunteers, at a concentration similar to that observed after a $24 \mathrm{~h}$ fast, has been shown to increase appetite and food intake at a buffet-style meal by almost 30\%.' Subcutaneous injection has also been shown to significantly induce appetite and increase food intake. ${ }^{80}$ In obese subjects, fasting ghrelin levels have been shown to be lower compared with normal weight controls and to rise following diet-induced weight loss. ${ }^{81}$ The typically expected post-prandial fall in circulating ghrelin levels is also attenuated, or even absent in the obese, ${ }^{82}$ suggestive of a role of ghrelin in the pathophysiology of obesity. ${ }^{83}$ In contrast, circulating ghrelin levels have been reported as being markedly reduced post-Gl surgery, thus potentially enhancing the weight-reducing effect of the procedure. ${ }^{81}$ Since this initial study, however, numerous other studies have reported no changes 84,85 and increases ${ }^{86,87}$ in circulating fasting and post-prandial ghrelin levels following $\mathrm{Gl}$ surgery, thus highlighting the incomplete understanding of the effect of the surgery on circulating levels of this orexigenic gut hormone. More convincing evidence for the role of ghrelin in energy homeostasis requires that blockage of its signaling results in a decrease in body weight. ${ }^{88}$ Pharmacological blockage of ghrelin has been shown to result in decreases in food intake and body weight in rodents, ${ }^{77}$ and ghrelin- or ghrelin receptor-deficient rodents are resistant to diet-induced obesity. ${ }^{89,90}$ In diet-induced obese mice, the selective ghrelin receptor antagonist YIL-870 has been shown to promote significant weight reduction through fat mass loss, attributable to the centrally-mediated anorexigenic effects of blocking the growth hormone secretagogue receptor. ${ }^{91}$ More evidence is required in support of these findings in humans. It is now well established that ghrelin has a role in overall energy homeostasis, but the pathways that mediate its effects and its role in the effects of $\mathrm{Gl}$ surgery require further characterization. Weight gain prevention through pre-prandial receptor blockade may represent the most promising role of ghrelin as a useful future anti-obesity agent.

\section{Pancreatic polypeptide}

The 36-amino acid anorexigenic peptide PP, is primarily synthesized and released from the endocrine pancreas, ${ }^{15}$ and to a lesser extent, from the colon and rectum. ${ }^{5}$ Levels are low during the fasting state and rise in proportion to caloric intake. ${ }^{92}$ Interest in the pharmacological targeting of the $Y$ family of $G$ proteincoupled receptors as an anti-obesity strategy has grown significantly in recent years. ${ }^{93}$ Although PP can function on all $Y$ receptors, it has been shown to have the highest affinity for the Y4 receptor, ${ }^{94}$ with food intake reduction being completely abolished in Y4 receptor knockout rodents. ${ }^{95}$ Peripherally-administered PP reportedly leads to a reduction in food intake, in both rodents and humans. ${ }^{7,96}$ Peripheral PP administration has also been demonstrated to lead to an increase in energy expenditure and a reduction in body weight in rodents, ${ }^{97}$ and a demonstrated 
reduction in appetite and food intake in both lean and obese humans has shed further light on its potential anti-obesity utility. ${ }^{7}$ The reported appetite- and energy balance-modulating effects of PP Y4 agonism have been most notably attributed to indirect actions via the brainstem, particularly through modulation of digestive processes, yet the hypothalamus is also believed to have a critical role in PP-mediated food intake reduction. ${ }^{97}$ The hypothalamic ARC, which is accessible to $P P,{ }^{98}$ expresses $Y 4$ receptors, and administration of PP over a $24 \mathrm{~h}$ period in mice has been shown to lead to a significant reduction in NPY mRNA expression. ${ }^{97}$ Despite its demonstrated anorexigenic effects and its possible anti-obesity utility, the exact hypothalamic nuclei and downstream pathways through which PP Y4 agonism functions to regulate food intake and body weight have, however, yet to be fully elucidated.99 $\mathrm{A}$ recent study in mice has demonstrated the peripheral PP-mediated suppression of orexigenic pathways in the lateral hypothalamic area, or 'feeding centre', and upregulation of anorexigenic pathways in the ventromedial hypothalamus, or 'satiety centre'. ${ }^{99}$ These effects were shown to be mediated via the Y4 receptor, as they were not reproducible in Y4 receptor knockout mice. Although the hypothalamically-regulated anorexigenic effects of PP remain to be fully characterized, a product with the capacity to increase endogenous PP production while avoiding degradation in the circulation, or to increase Y4-mediated signaling, would certainly hold promise as a future anti-obesity tool.

\section{Peptide YY}

PYY, a member of the PP-fold family of proteins to which PP also belongs, is so named because of the tyrosine residues at both its $\mathrm{N}$ - and C-termini. ${ }^{100}$ The full-length 36 -amino acid peptide is synthesized and released from the L-cells of the GI tract, however, most PYY in the circulation is in the 34-amino acid PYY ${ }_{3-36}$ form, having been truncated at the N-terminus. ${ }^{101}$ Circulating levels of $\mathrm{PYY}_{3-36}$ are influenced by meal composition and calorie content, and become elevated within $1 \mathrm{~h}$ post-feeding. ${ }^{102}$ Similar to PP, peripherally-administered $\mathrm{PYY}_{3-36}$ exerts its food intake-inhibiting effects via the $Y$ family of $G$ protein-coupled receptors, but with preferentiality for the Y2 receptor. ${ }^{103}$ Inhibition of food intake in response to administration of a selective $\mathrm{Y} 2$ agonist, ${ }^{104}$ and attenuation of this inhibitory effect in response to Y2 antagonists, ${ }^{105}$ have provided evidence for this finding. As circulating PYY $_{3-36}$ levels are often lower in the obese state, it has been suggested that this characteristic may in fact have a causative role in the development of obesity. ${ }^{106}$ From a therapeutic utility standpoint, $\mathrm{PYY}_{3-36}$ has been shown to have anorexigenic effects in not only normal weight individuals, but also in the obese. In a trial consisting of both lean and obese humans, PYY $3-36$ administration (intravenous) lead to a decrease in appetite and an almost $30 \%$ restriction in caloric intake in both groups. ${ }^{107}$ With the anorexigenic capabilities of exogenous $\mathrm{PYY}_{3-36}$ being fully intact in the obese, resistance is not thought to exist in the obese state, and this has encouraged longer-term weight loss studies involving chronic administration. Significant increases in circulating $\mathrm{PYY}_{3-36}$ levels have also been reported post-Gl surgery, ${ }^{108}$ possibly contributing to the initial and long-term sustainment of weight loss attributed to the procedure. Development of a $\mathrm{PYY}_{3-36}$ nasal spray for thrice daily administration has been shown to result in modest weight reductions in humans, ${ }^{109}$ however, side effects including nausea and vomiting were encountered during clinical trials. This, in addition to previously reported nausea and conditioned taste aversion in mice in response to food intakelowering dosages, ${ }^{110}$ has placed limitations on the utility of $\mathrm{PYY}_{3-36}$ or $\mathrm{Y} 2$ receptor agonists as anti-obesity agents. Development of more potent analogs, different administration routes or dosing regiments, or novel combinatorial approaches with other gut hormones may help unlock the future potential of $\mathrm{PYY}_{3-36}$ as an anti-obesity therapy.

\section{Glucagon-like peptide (GLP)-1}

In the gut, GLP-1 is released from small intestinal and colonic L-cells in proportion to ingested calories. ${ }^{111}$ In both lean and obese humans, peripherally-administered GLP-1 has been shown to exert anorexigenic effects, ${ }^{112,113}$ with other possible influences on food intake being linked to a reduction in gastric emptying and a suppression of gastric acid secretion. ${ }^{114}$ Both centrally- and peripherally-administered GLP-1 or GLP-1 receptor agonists have been shown to enhance satiety, reduce food intake, and promote weight loss in rodents and humans. ${ }^{115-117}$ Obese individuals have been reported to elicit delays in the post-prandial release of GLP-1, and thus present with reduced circulating levels of the peptide. ${ }^{118}$ Nonetheless, they remain sensitive to peripherally-administered GLP-1 and its anorexigenic effects. ${ }^{113}$ As with PYY, Gl surgery has been shown to enhance the post-prandial GLP-1 response. ${ }^{119}$ Because of inactivation and clearance by the enzyme dipeptidyl peptidase-IV (DPP-IV), the half-life of GLP-1 is an estimated 5 min, thus presenting a major hurdle down the path to its possible therapeutic utility. Currently investigated approaches against the short half-life of GLP-1 include DDP-IV inhibition and the development of more stable GLP-1 analogs. ${ }^{120}$ Inhibition of DPP-IV has had useful applications in the treatment of T2DM, ${ }^{121}$ but less promising results have been demonstrated in terms of its antiobesity utility. ${ }^{120}$ The development of non-peptidic or DPP-IV resistant GLP-1 receptor agonists have, therefore, been garnering more recent attention, and may show more promise as antiobesity therapies. The GLP-1 analog, exendin-4, discovered from the venom of the Gila monster, Heloderma suspectum, ${ }^{122}$ is now being investigated as an anti-obesity agent in non-diabetic humans. Minor, yet adverse side effects, including nausea and vomiting have, however, been reported, ${ }^{120}$ thereby placing limitations on its use in terms of a maximum tolerable dose. The highly homologous, long half-life GLP-1 analog, liraglutide, has also been demonstrated as a well-tolerated body weightreducing pharmacological agent in humans, yet transient nausea remains to be the most common side effect. ${ }^{117,123}$ Analogs with greater similarity to the human form of GLP-1 are now in trial, and determination of their efficacy as anti-obesity agents is ongoing. ${ }^{120}$ Further to the currently investigated approaches, future research aimed at better understanding the mechanisms involved in endogenous GLP-1 production would be beneficial. With the known additive satiating effects of GLP-1 and PYY, ${ }^{124}$ exploiting endogenous GLP-1 production may also yield a novel combinatorial anti-obesity approach.

\section{Oxyntomodulin}

Early work in rats on a peptide with inhibitory action on stomach oxyntic glands lead to the advent of the name OXM for the now well established gut hormone. ${ }^{125}$ OXM shares the same precursor molecule as GLP-1, is co-secreted with GLP-1 following feeding, and its release is also proportional to meal calorie content. ${ }^{126}$ Centrally- and peripherally-administered OXM reduces food intake and increases energy expenditure in rodents, and reductions in body weight have been reported in response to chronic injections. ${ }^{127}$ Peripheral administration in humans increases satiation and reduces food intake, with repeated injections leading to decreases in body weight. ${ }^{128}$ There has also been data in support of OXM promoting increased energy expenditure in humans. ${ }^{129}$ The anorexigenic mechanism of action of OXM remains unclear and its role in the pathogenesis of obesity has been largely uninvestigated. ${ }^{120}$ Furthermore, a specific OXM receptor has yet to be discovered. ${ }^{5}$ As injection of GLP-1 receptor antagonists into the ARC has been demonstrated to block the anorexigenic effects of OXM, ${ }^{127}$ it has been proposed that 
OXM might signal via the GLP-1 receptor, although its receptorbinding affinity is significantly lower. ${ }^{130}$ Furthermore, it has recently been shown that OXM requires the GLP-1 receptor, as its effect is abolished in GLP-1 receptor knockout mice. ${ }^{131}$ It is also possible that an unknown OXM receptor exists, yet it would almost certainly share similarities with the GLP-1 receptor. Despite the probable involvement of the GLP-1 receptor in OXM signaling, the pathways are likely separate. ${ }^{127}$ At equal concentrations, both GLP-1 and OXM elicit anorexigenic effects, despite the large disparity in GLP-1 receptor-binding affinity. ${ }^{129}$ Similar to GLP-1, the potential therapeutic utility of OXM may, in part, be hindered due to its inactivation by DPP-IV, ${ }^{5}$ although its effects on food intake in humans are more potent, ${ }^{132}$ and it is reported to cause less nausea than GLP-1. ${ }^{15} \mathrm{~A}$ recent trial investigating the OXM analog TKS1225 has demonstrated the increasing desirability to develop OXM into an anti-obesity agent. Eliciting comparable satiating effects to GLP-1, ${ }^{133}$ along with the already well demonstrated anti-obesity potential of GLP-1, OXM may equally present as a strong gut hormone candidate for combating against the obesity epidemic.

\section{SUMMARY}

The prevalence of obesity and its associated co-morbidities has increased substantially in the last number of decades, and the disease is now widely considered to be a global epidemic. Currently, among approved anti-obesity therapies, only Gl surgery can effectively lead to substantial weight loss results, accompanied by long-term sustainability. ${ }^{129}$ However, Gl surgery has largely been rendered impractical as a useful anti-obesity strategy, in large part due to its high cost and rate of mortality. There has, however, been increasingly convincing evidence that the resulting weight loss following the surgery is due, at least in part, to an alteration in the circulating levels and physiology of certain gut hormones. ${ }^{1,63}$ Stimulated release of anorexigenic peptides such as CCK, PP, PYY, GLP-1, and OXM, and diminished release of the orexigenic peptide ghrelin, have been documented. ${ }^{63}$ In contrast to some of the currently used, relatively non-specific drug therapies, gut hormones function specifically on systems responsible for appetite control. ${ }^{129}$ In addition, due to their natural physiological regulation of appetite, gut hormone-based therapies are less likely to cause adverse side effects than some of the currently approved drugs, ${ }^{15}$ thus potentially offering a safer, more attractive alternative approach to combat the obesity epidemic. Although the gut-brain axis and a variety of hormone signaling pathways have been emerging as potentially powerful antiobesity tools, the short half-life of many of the endogenous gut hormones must be considered. ${ }^{128,129}$ Receptor agonists and alternative delivery routes have both been postulated to allow for circumvention of this unfortunate characteristic, and to aid in the future development of gut hormone-based anti-obesity therapies. ${ }^{15}$ In conclusion, continued research into the potential to pharmacologically exploit endogenously occurring appetite-regulating gut hormones in an effort to regulate energy homeostasis is required, but certainly holds great promise to lead to the development of safe and effective anti-obesity treatments, and to contribute to the effort of combating the rampant global rise in obesity. The evidence presented herein strongly indicates that obesity research and the development of weight loss or weight management products should focus on the release and function of gut hormones, in connection to their association with receptors in the CNS, in particular the hypothalamus.

\section{CONFLICT OF INTEREST}

The authors declare no conflict of interest.

\section{REFERENCES}

1 Murphy KG, Bloom SR. Gut hormones in the control of appetite. Exp Physiol 2004; 89: $507-516$.

2 Hedley AA, Ogden CL, Johnson CL, Carroll MD, Curtin LR, Flegal KM. Prevalence of overweight and obesity among US children, adolescents, and adults, 1999-2002. Jama 2004; 291: 2847-2850.

3 Small CJ, Bloom SR. Gut hormones and the control of appetite. Trends Endocrinol Metab 2004; 15: 259-263.

4 Woods SC, D'Alessio DA. Central control of body weight and appetite. J Clin Endocrinol Metab 2008; 93 (11 Suppl 1): S37-S50.

5 Hameed S, Dhillo WS, Bloom SR. Gut hormones and appetite control. Oral Dis 2009; 15: $18-26$

6 Tschop M, Weyer C, Tataranni PA, Devanarayan V, Ravussin E, Heiman ML. Circulating ghrelin levels are decreased in human obesity. Diabetes 2001; 50: 707-709.

7 Batterham RL, Le Roux CW, Cohen MA, Park AJ, Ellis SM, Patterson M et al. Pancreatic polypeptide reduces appetite and food intake in humans. J Clin Endocrinol Metab 2003; 88: 3989-3992.

8 Frandsen J, Pedersen SB, Richelsen B. Long term follow up of patients who underwent jejunoileal bypass for morbid obesity. Eur J Surg 1998; 164: 281 -286.

9 Vettor R, Fabris R, Pagano C, Federspil G. Neuroendocrine regulation of eating behavior. J Endocrinol Invest 2002; 25: 836-854.

10 Kalra SP, Dube MG, Pu S, Xu B, Horvath TL, Kalra PS. Interacting appetiteregulating pathways in the hypothalamic regulation of body weight. Endocr Rev 1999; 20: $68-100$.

11 Wilding JP. Neuropeptides and appetite control. Diabet Med 2002; 19: 619-627.

12 Kaiyala KJ, Woods SC, Schwartz MW. New model for the regulation of energy balance and adiposity by the central nervous system. Am J Clin Nutr 1995; 62 (5 Suppl): 1123S-1134S.

13 Williams G, Bing C, Cai XJ, Harrold JA, King PJ, Liu XH. The hypothalamus and the control of energy homeostasis: different circuits, different purposes. Physiol Behav 2001; 74: 683-701.

14 Cone RD, Cowley MA, Butler AA, Fan W, Marks DL, Low MJ. The arcuate nucleus as a conduit for diverse signals relevant to energy homeostasis. Int $J$ Obes Relat Metab Disord 2001; 25 (Suppl 5): S63-S67.

15 Chaudhri OB, Wynne K, Bloom SR. Can gut hormones control appetite and prevent obesity? Diabetes Care 2008; 31 (Suppl 2): S284-S289.

16 Kennedy GC. The role of depot fat in the hypothalamic control of food intake in the rat. Proc $R$ Soc Lond B Biol Sci 1953; 140: 578-596.

17 Zhang Y, Proenca R, Maffei M, Barone M, Leopold L, Friedman JM. Positional cloning of the mouse obese gene and its human homologue. Nature 1994; 372: 425-432.

18 Friedman JM, Halaas JL. Leptin and the regulation of body weight in mammals. Nature 1998; 395: $763-770$

19 Sahu A. Leptin signaling in the hypothalamus: emphasis on energy homeostasis and leptin resistance. Front Neuroendocrinol 2003; 24: 225-253.

20 Montague CT, Farooqi IS, Whitehead JP, Soos MA, Rau H, Wareham NJ et al. Congenital leptin deficiency is associated with severe early-onset obesity in humans. Nature 1997; 387: 903 -908.

21 Paz-Filho GJ, Volaco A, Suplicy HL, Radominski RB, Boguszewski CL. Decrease in leptin production by the adipose tissue in obesity associated with severe metabolic syndrome. Arq Bras Endocrinol Metabol 2009; 53: 1088-1095.

22 Farooqi IS, Jebb SA, Langmack G, Lawrence E, Cheetham CH, Prentice AM et al. Effects of recombinant leptin therapy in a child with congenital leptin deficiency. N Engl J Med 1999; 341: 879-884.

23 Maffei M, Halaas J, Ravussin E, Pratley RE, Lee GH, Zhang $Y$ et al. Leptin levels in human and rodent: measurement of plasma leptin and ob RNA in obese and weight-reduced subjects. Nat Med 1995; 1: 1155-1161.

24 Enriori $\mathrm{PJ}$, Evans $\mathrm{AE}$, Sinnayah $\mathrm{P}$, Jobst $\mathrm{EE}$, Tonelli-Lemos $\mathrm{L}$, Billes $\mathrm{SK}$ et al. Diet-induced obesity causes severe but reversible leptin resistance in arcuate melanocortin neurons. Cell Metab 2007; 5: 181 - 194.

25 Rabe K, Lehrke M, Parhofer KG, Broedl UC. Adipokines and insulin resistance. Mol Med 2008; 14: $741-751$

26 Knight ZA, Hannan KS, Greenberg ML, Friedman JM. Hyperleptinemia is required for the development of leptin resistance. PLoS One 2010; 5: e11376.

27 Munzberg $\mathrm{H}$, Flier JS, Bjorbaek C. Region-specific leptin resistance within the hypothalamus of diet-induced obese mice. Endocrinology 2004; 145: 4880 - 4889.

28 Kalra SP. Central leptin insufficiency syndrome: an interactive etiology for obesity, metabolic and neural diseases and for designing new therapeutic interventions. Peptides 2008; 29: 127-138.

29 Garcia-San Frutos M, Fernandez-Agullo T, De Solis AJ, Andres A, Arribas C, Carrascosa JM et al. Impaired central insulin response in aged Wistar rats: role of adiposity. Endocrinology 2007; 148: 5238-5247.

30 Rocha PM, Barata JT, Minderico CS, Silva AM, Teixeira PJ, Sardinha LB. Visceral abdominal and subfascial femoral adipose tissue have opposite associations with liver fat in overweight and obese premenopausal caucasian women. J Lipids; 2011; 2011: 154672. 
31 Air EL, Benoit SC, Blake Smith KA, Clegg DJ, Woods SC. Acute third ventricular administration of insulin decreases food intake in two paradigms. Pharmacol Biochem Behav 2002; 72: 423 - 429 .

32 Kieffer TJ, Habener JF. The adipoinsular axis: effects of leptin on pancreatic beta-cells. Am J Physiol Endocrinol Metab 2000; 278: E1-E14.

33 Carvalheira JB, Torsoni MA, Ueno M, Amaral ME, Araujo EP, Velloso LA et al. Cross-talk between the insulin and leptin signaling systems in rat hypothalamus. Obes Res 2005; 13: 48- 57.

34 Adam TC, Toledo-Corral C, Lane CJ, Weigensberg MJ, Spruijt-Metz D, Davies JN et al. Insulin sensitivity as an independent predictor of fat mass gain in Hispanic adolescents. Diabetes Care 2009; 32: 2114-2115.

35 Morrison JA, Glueck CJ, Horn PS, Schreiber GB, Wang P. Pre-teen insulin resistance predicts weight gain, impaired fasting glucose, and type 2 diabetes at age 18-19 y: a 10-y prospective study of black and white girls. Am J Clin Nutr 2008; 88: $778-788$.

36 Eu CH, Lim WY, Ton SH, bin Abdul Kadir K. Glycyrrhizic acid improved lipoprotein lipase expression, insulin sensitivity, serum lipid and lipid deposition in high-fat diet-induced obese rats. Lipids Health Dis 2010; 9: 81

37 Wang ZQ, Ribnicky D, Zhang XH, Raskin I, Yu Y, Cefalu WT. Bioactives of Artemisia dracunculus $L$ enhance cellular insulin signaling in primary human skeletal muscle culture. Metabolism 2008; 57 (7 Suppl 1): S58-S64.

38 Hundal RS, Krssak M, Dufour S, Laurent D, Lebon V, Chandramouli V et al. Mechanism by which metformin reduces glucose production in type 2 diabetes. Diabetes 2000; 49: 2063 - 2069.

39 Cigolini M, Bosello O, Zancanaro C, Orlandi PG, Fezzi O, Smith U. Influence of metformin on metabolic effect of insulin in human adipose tissue in vitro. Diabete Metab 1984; 10: $311-315$

40 Lee A, Morley JE. Metformin decreases food consumption and induces weight loss in subjects with obesity with type II non-insulin-dependent diabetes. Obes Res 1998; 6: 47-53.

41 Salpeter SR, Buckley NS, Kahn JA, Salpeter EE. Meta-analysis: metformin treatment in persons at risk for diabetes mellitus. Am J Med 2008; 121 $149-157 e 2$.

42 Love-Osborne K, Sheeder J, Zeitler P. Addition of metformin to a lifestyle modification program in adolescents with insulin resistance. J Pediatr 2008; 152 $817-822$

$43 \mathrm{Fu}$ JF, Liang L, Zou CC, Hong F, Wang CL, Wang XM et al. Prevalence of the metabolic syndrome in Zhejiang Chinese obese children and adolescents and the effect of metformin combined with lifestyle intervention. Int J Obes (Lond) 2007; 31: 15-22.

44 Nissen SE, Wolski K. Effect of rosiglitazone on the risk of myocardial infarction and death from cardiovascular causes. N Engl J Med 2007; 356: 2457-2471.

45 Wang Y, Campbell T, Perry B, Beaurepaire C, Qin L. Hypoglycemic and insulinsensitizing effects of berberine in high-fat diet- and streptozotocin-induced diabetic rats. Metabolism 2011; 60: 298-305.

46 Figlewicz DP. Adiposity signals and food reward: expanding the CNS roles of insulin and leptin. Am J Physiol Regul Integr Comp Physiol 2003; 284: R882 - R892.

47 Megalli S, Davies NM, Roufogalis BD. Anti-hyperlipidemic and hypoglycemic effects of Gynostemma pentaphyllum in the Zucker fatty rat. J Pharm Pharm SCi 2006; 9: 281 - 291.

48 Batterham RL, Cowley MA, Small CJ, Herzog H, Cohen MA, Dakin CL et al. Gut hormone PYY(3-36) physiologically inhibits food intake. Nature 2002; 418: $650-654$

49 Ishii Y, Blundell JE, Halford JC, Rodgers RJ. Palatability, food intake and the behavioural satiety sequence in male rats. Physiol Behav 2003; 80: 37-47.

50 Saper CB, Chou TC, Elmquist JK. The need to feed: homeostatic and hedonic control of eating. Neuron 2002; 36: 199-211.

51 Pournaras DJ, Le Roux CW. The effect of bariatric surgery on gut hormones that alter appetite. Diabetes Metab 2009; 35 (6 Part 2): 508-512.

52 le Roux CW, Aylwin SJ, Batterham RL, Borg CM, Coyle F, Prasad V et al. Gut hormone profiles following bariatric surgery favor an anorectic state, facilitate weight loss, and improve metabolic parameters. Ann Surg 2006; 243: 108 - 114

53 Gibbs J, Young RC, Smith GP. Cholecystokinin elicits satiety in rats with open gastric fistulas. Nature 1973; 245: $323-325$

54 Lieverse RJ, Jansen JB, Masclee AA, Lamers CB. Satiety effects of a physiological dose of cholecystokinin in humans. Gut 1995; 36: 176-179.

55 Liddle RA, Goldfine ID, Rosen MS, Taplitz RA, Williams JA. Cholecystokinin bioactivity in human plasma. Molecular forms, responses to feeding, and relationship to gallbladder contraction. J Clin Invest 1985; 75: 1144-1152.

56 Buffa R, Solcia E, Go VL. Immunohistochemical identification of the cholecystokinin cell in the intestinal mucosa. Gastroenterology 1976; 70: 528-532.

57 Dufresne M, Seva C, Fourmy D. Cholecystokinin and gastrin receptors. Physiol Rev 2006; 86: $805-847$

58 Moran TH, Schwartz GJ. Neurobiology of cholecystokinin. Crit Rev Neurobiol 1994; 9: $1-28$
59 Matson CA, Reid DF, Cannon TA, Ritter RC. Cholecystokinin and leptin act synergistically to reduce body weight. Am J Physiol Regul Integr Comp Physiol 2000; 278: R882 - R890.

60 Kissileff HR, Pi-Sunyer FX, Thornton J, Smith GP. C-terminal octapeptide of cholecystokinin decreases food intake in man. Am J Clin Nutr 1981; 34: $154-160$

61 West DB, Fey D, Woods SC. Cholecystokinin persistently suppresses meal size but not food intake in free-feeding rats. Am J Physiol 1984; 246 (5 Part 2): R776-R787.

62 Crawley JN, Beinfeld MC. Rapid development of tolerance to the behavioural actions of cholecystokinin. Nature 1983; 302: $703-706$.

63 Cummings DE, Overduin J. Gastrointestinal regulation of food intake. J Clin Invest 2007; 117: $13-23$

64 Rubino F, Gagner M, Gentileschi P, Kini S, Fukuyama S, Feng J et al. The early effect of the Roux-en-Y gastric bypass on hormones involved in body weight regulation and glucose metabolism. Ann Surg 2004; 240: 236-242.

65 Savastano DM, Covasa M. Intestinal nutrients elicit satiation through concomitant activation of CCK(1) and 5-HT(3) receptors. Physiol Behav 2007 92: $434-442$.

66 Melville LD, Smith GP, Gibbs J. Devazepide antagonizes the inhibitory effect of cholecystokinin on intake in sham-feeding rats. Pharmacol Biochem Behav 1992; 43: $975-977$.

67 Beglinger C, Degen L, Matzinger D, D'Amato M, Drewe J. Loxiglumide, a CCK-A receptor antagonist, stimulates calorie intake and hunger feelings in humans. Am J Physiol Regul Integr Comp Physiol 2001; 280: R1149-R1154.

68 Szewczyk JR, Laudeman C. CCK1R agonists: a promising target for the pharmacological treatment of obesity. Curr Top Med Chem 2003; 3: 837-854.

69 Moran TH, Katz LF, Plata-Salaman CR, Schwartz GJ. Disordered food intake and obesity in rats lacking cholecystokinin A receptors. Am J Physiol 1998; 274 (3 Part 2): R618-R625.

70 Moran $\mathrm{TH}, \mathrm{Bi}$ S. Hyperphagia and obesity in OLETF rats lacking CCK-1 receptors. Philos Trans R Soc Lond B Biol Sci 2006; 361: 1211 - 1218.

71 Castillo EJ, Delgado-Aros S, Camilleri M, Burton D, Stephens D, O'ConnorSemmes $\mathrm{R}$ et al. Effect of oral CCK-1 agonist GI181771X on fasting and postprandial gastric functions in healthy volunteers. Am J Physiol Gastrointest Liver Physiol 2004; 287: G363-G369.

72 Jordan J, Greenway FL, Leiter LA, Li Z, Jacobson P, Murphy K et al. Stimulation of cholecystokinin-A receptors with Gl181771X does not cause weight loss in overweight or obese patients. Clin Pharmacol Ther 2008; 83: $281-287$.

73 Kojima M, Hosoda H, Date Y, Nakazato M, Matsuo H, Kangawa K. Ghrelin is a growth-hormone-releasing acylated peptide from stomach. Nature 1999; 402 $656-660$.

74 Bailey AR, Von Englehardt N, Leng G, Smith RG, Dickson SL. Growth hormone secretagogue activation of the arcuate nucleus and brainstem occurs via a nonnoradrenergic pathway. J Neuroendocrinol 2000; 12: 191 - 197.

75 Wren AM, Small CJ, Abbott CR, Dhillo WS, Seal LJ, Cohen MA et al. Ghrelin causes hyperphagia and obesity in rats. Diabetes 2001; 50: 2540-2547.

76 Willesen MG, Kristensen P, Romer J. Co-localization of growth hormone secretagogue receptor and NPY mRNA in the arcuate nucleus of the rat. Neuroendocrinology 1999; 70: 306-316.

77 Tschop M, Smiley DL, Heiman ML. Ghrelin induces adiposity in rodents. Nature 2000; 407: $908-913$.

78 Wren AM, Seal L, Cohen MA, Brynes AE, Frost GS, Murphy KG et al. Ghrelin enhances appetite and increases food intake in humans. $J$ Clin Endocrinol Metab 2001; 86: 5992.

79 Druce MR, Wren AM, Park AJ, Milton JE, Patterson M, Frost G et al. Ghrelin increases food intake in obese as well as lean subjects. Int J Obes (Lond) 2005; 29 $1130-1136$

80 Druce MR, Neary NM, Small CJ, Milton J, Monteiro M, Patterson $M$ et al. Subcutaneous administration of ghrelin stimulates energy intake in healthy lean human volunteers. Int J Obes (Lond) 2006; 30: 293-296.

81 Cummings DE, Weigle DS, Frayo RS, Breen PA, Ma MK, Dellinger EP et al. Plasma ghrelin levels after diet-induced weight loss or gastric bypass surgery. $N$ Engl J Med 2002; 346: 1623 - 1630

82 English PJ, Ghatei MA, Malik IA, Bloom SR, Wilding JP. Food fails to suppress ghrelin levels in obese humans. J Clin Endocrinol Metab 2002; 87: 2984.

83 le Roux CW, Patterson M, Vincent RP, Hunt C, Ghatei MA, Bloom SR. Postprandial plasma ghrelin is suppressed proportional to meal calorie content in normalweight but not obese subjects. J Clin Endocrinol Metab 2005; 90: 1068-1071.

84 Karamanakos SN, Vagenas K, Kalfarentzos F, Alexandrides TK. Weight loss, appetite suppression, and changes in fasting and postprandial ghrelin and peptide-YY levels after Roux-en-Y gastric bypass and sleeve gastrectomy: a prospective, double blind study. Ann Surg 2008; 247: $401-407$.

85 Couce ME, Cottam D, Esplen J, Schauer P, Burguera B. Is ghrelin the culprit fo weight loss after gastric bypass surgery? A negative answer. Obes Surg 2006; 16 $870-878$ 
86 Garcia-Fuentes E, Garrido-Sanchez L, Garcia-Almeida JM, Garcia-Arnes J, Gallego-Perales JL, Rivas-Marin J et al. Different effect of laparoscopic Rouxen-Y gastric bypass and open biliopancreatic diversion of Scopinaro on serum PYY and ghrelin levels. Obes Surg 2008; 18: 1424 - 1429.

87 Ybarra J, Bobbioni-Harsch E, Chassot G, Huber O, Morel P, AssimacopoulosJeannet $\mathrm{F}$ et al. Persistent correlation of ghrelin plasma levels with body mass index both in stable weight conditions and during gastric-bypass-induced weight loss. Obes Surg 2009; 19: 327-331.

88 Foster-Schubert KE, Cummings DE. Emerging therapeutic strategies for obesity. Endocr Rev 2006; 27: 779-793.

89 Wortley KE, del Rincon JP, Murray JD, Garcia K, lida K, Thorner MO et al. Absence of ghrelin protects against early-onset obesity. J Clin Invest 2005; 115 $3573-3578$.

90 Zigman JM, Nakano Y, Coppari R, Balthasar N, Marcus JN, Lee CE et al. Mice lacking ghrelin receptors resist the development of diet-induced obesity. J Clin Invest 2005; 115: 3564-3572.

91 Esler WP, Rudolph J, Claus TH, Tang W, Barucci N, Brown SE et al. Small-molecule ghrelin receptor antagonists improve glucose tolerance, suppress appetite, and promote weight loss. Endocrinology 2007; 148: 5175 - 5185.

92 Track NS, McLeod RS, Mee AV. Human pancreatic polypeptide: studies of fasting and postprandial plasma concentrations. Can J Physiol Pharmacol 1980; 58: $1484-1489$.

93 Lin S, Shi YC, Yulyaningsih E, Aljanova A, Zhang L, Macia L et al. Critical role of arcuate $Y 4$ receptors and the melanocortin system in pancreatic polypeptideinduced reduction in food intake in mice. PLoS One 2009; 4: e8488.

94 Blomqvist AG, Herzog H. Y-receptor subtypes--how many more? Trends Neurosci 1997; 20: 294-298

95 Balasubramaniam A, Mullins DE, Lin S, Zhai W, Tao Z, Dhawan VC et al. Neuropeptide $Y$ (NPY) Y4 receptor selective agonists based on NPY(32-36): development of an anorectic Y4 receptor selective agonist with picomolar affinity. J Med Chem 2006; 49: $2661-2665$

96 Malaisse-Lagae F, Carpentier JL, Patel YC, Malaisse WJ, Orci L. Pancreatic polypeptide: a possible role in the regulation of food intake in the mouse. Hypothesis. Experientia 1977; 33: 915-917.

97 Asakawa A, Inui A, Yuzuriha $\mathrm{H}$, Ueno N, Katsuura G, Fujimiya $M$ et al. Characterization of the effects of pancreatic polypeptide in the regulation of energy balance. Gastroenterology 2003; 124: 1325 - 1336.

98 Jobst EE, Enriori PJ, Cowley MA. The electrophysiology of feeding circuits. Trends Endocrinol Metab 2004; 15: 488-499.

99 Sainsbury A, Shi YC, Zhang L, Aljanova A, Lin Z, Nguyen AD et al. Y4 receptors and pancreatic polypeptide regulate food intake via hypothalamic orexin and brainderived neurotropic factor dependent pathways. Neuropeptides 2010; 44: 261 - 268.

100 Tatemoto K, Mutt V. Isolation of two novel candidate hormones using a chemical method for finding naturally occurring polypeptides. Nature 1980; 285: 417-418.

101 Grandt D, Schimiczek M, Beglinger C, Layer P, Goebell H, Eysselein VE et al. Two molecular forms of peptide YY (PYY) are abundant in human blood characterization of a radioimmunoassay recognizing PYY 1-36 and PYY 3-36. Regul Pept 1994; 51: 151 - 159.

102 Adrian TE, Ferri GL, Bacarese-Hamilton AJ, Fuessl HS, Polak JM, Bloom SR. Human distribution and release of a putative new gut hormone, peptide YY. Gastroenterology 1985; 89: 1070-1077.

103 Keire DA, Mannon P, Kobayashi M, Walsh JH, Solomon TE, Reeve Jr JR. Primary structures of PYY, [Pro(34)]PYY, and PYY-(3-36) confer different conformations and receptor selectivity. Am J Physiol Gastrointest Liver Physiol 2000; 279: G126-G131.

104 Lumb KJ, DeCarr LB, Milardo LF, Mays MR, Buckholz TM, Fisk SE et al. Novel selective neuropeptide $\mathrm{Y} 2$ receptor PEGylated peptide agonists reduce food intake and body weight in mice. J Med Chem 2007; 50: 2264-2268.

105 Abbott CR, Small CJ, Kennedy AR, Neary NM, Sajedi A, Ghatei MA et al. Blockade of the neuropeptide $Y$ Y2 receptor with the specific antagonist BIIE0246 attenuates the effect of endogenous and exogenous peptide YY(3-36) on food intake. Brain Res 2005; 1043: 139-144.

106 le Roux CW, Batterham RL, Aylwin SJ, Patterson M, Borg CM, Wynne KJ et al. Attenuated peptide $Y Y$ release in obese subjects is associated with reduced satiety. Endocrinology 2006; 147: 3-8.

107 Batterham RL, Cohen MA, Ellis SM, Le Roux CW, Withers DJ, Frost GS et al. Inhibition of food intake in obese subjects by peptide YY3-36. N Engl J Med 2003; 349: 941 - 948.

108 Korner J, Bessler M, Cirilo LJ, Conwell IM, Daud A, Restuccia NL et al. Effects of Roux-en-Y gastric bypass surgery on fasting and postprandial concentrations of plasma ghrelin, peptide YY, and insulin. J Clin Endocrinol Metab 2005; 90: 359-365.

109 Gantz I, Erondu N, Mallick M, Musser B, Krishna R, Tanaka WK et al. Efficacy and safety of intranasal peptide YY3-36 for weight reduction in obese adults. J Clin Endocrinol Metab 2007; 92: 1754 - 1757.

110 Halatchev IG, Cone RD. Peripheral administration of PYY(3-36) produces conditioned taste aversion in mice. Cell Metab 2005; 1: 159-168.
111 Herrmann C, Goke R, Richter G, Fehmann HC, Arnold R, Goke B. Glucagon-like peptide-1 and glucose-dependent insulin-releasing polypeptide plasma levels in response to nutrients. Digestion 1995; 56: 117-126.

112 Gutzwiller JP, Goke B, Drewe J, Hildebrand P, Ketterer S, Handschin D et al. Glucagon-like peptide-1: a potent regulator of food intake in humans. Gut 1999; 44: 81 - 86.

113 Naslund E, Barkeling B, King N, Gutniak M, Blundell JE, Holst JJ et al. Energy intake and appetite are suppressed by glucagon-like peptide-1 (GLP-1) in obese men. Int J Obes Relat Metab Disord 1999; 23: 304-311.

114 Verdich C, Flint A, Gutzwiller JP, Naslund E, Beglinger C, Hellstrom PM et al. A meta-analysis of the effect of glucagon-like peptide-1 (7-36) amide on ad libitum energy intake in humans. J Clin Endocrinol Metab 2001; 86: 4382-4389.

115 Turton MD, O'Shea D, Gunn I, Beak SA, Edwards CM, Meeran K et al. A role for glucagon-like peptide-1 in the central regulation of feeding. Nature 1996; 379: 69-72.

116 Tourrel C, Bailbe D, Meile MJ, Kergoat M, Portha B. Glucagon-like peptide-1 and exendin-4 stimulate beta-cell neogenesis in streptozotocin-treated newborn rats resulting in persistently improved glucose homeostasis at adult age. Diabetes 2001; 50: 1562 - 1570

117 Vilsboll T, Zdravkovic M, Le-Thi T, Krarup T, Schmitz O, Courreges JP et al. Liraglutide, a long-acting human glucagon-like peptide-1 analog, given as monotherapy significantly improves glycemic control and lowers body weight without risk of hypoglycemia in patients with type 2 diabetes. Diabetes Care 2007; 30: $1608-1610$

118 Verdich C, Toubro S, Buemann B, Lysgard Madsen J, Juul Holst J, Astrup A. The role of postprandial releases of insulin and incretin hormones in meal-induced satiety--effect of obesity and weight reduction. Int J Obes Relat Metab Disord 2001; 25: $1206-1214$

119 le Roux CW, Welbourn R, Werling M, Osborne A, Kokkinos A, Laurenius A et al. Gut hormones as mediators of appetite and weight loss after Roux-en-Y gastric bypass. Ann Surg 2007; 246: 780-785.

120 Neary MT, Batterham RL. Gut hormones: implications for the treatment of obesity. Pharmacol Ther 2009; 124: 44-56.

121 Ahren B, Winzell MS, Wierup N, Sundler F, Burkey B, Hughes TE. DPP-4 inhibition improves glucose tolerance and increases insulin and GLP-1 responses to gastric glucose in association with normalized islet topography in mice with beta-cellspecific overexpression of human islet amyloid polypeptide. Regul Pept 2007; 143: $97-103$

122 Eng J, Kleinman WA, Singh L, Singh G, Raufman JP. Isolation and characterization of exendin-4, an exendin-3 analogue, from Heloderma suspectum venom. Further evidence for an exendin receptor on dispersed acini from guinea pig pancreas. J Biol Chem 1992; 267: 7402 - 7405.

123 Rossi MC, Nicolucci A. Liraglutide in type 2 diabetes: from pharmacological development to clinical practice. Acta Biomed 2009; 80: 93 - 101.

124 Neary NM, Small CJ, Druce MR, Park AJ, Ellis SM, Semjonous NM et al. Peptide YY3-36 and glucagon-like peptide-17-36 inhibit food intake additively. Endocrinology 2005; 146: 5120-5127.

125 Dubrasquet M, Bataille D, Gespach C. Oxyntomodulin (glucagon-37 or bioactive enteroglucagon): a potent inhibitor of pentagastrin-stimulated acid secretion in rats. Biosci Rep 1982; 2: $391-395$

126 Druce MR, Bloom SR. Oxyntomodulin: a novel potential treatment for obesity. Treat Endocrinol 2006; 5: $265-272$

127 Dakin CL, Small CJ, Batterham RL, Neary NM, Cohen MA, Patterson M et al. Peripheral oxyntomodulin reduces food intake and body weight gain in rats. Endocrinology 2004; 145: 2687-2695.

128 Wynne K, Park AJ, Small CJ, Patterson M, Ellis SM, Murphy KG et al. Subcutaneous oxyntomodulin reduces body weight in overweight and obese subjects: a double-blind, randomized, controlled trial. Diabetes 2005; 54: 2390-2395.

129 Murphy KG, Dhillo WS, Bloom SR. Gut peptides in the regulation of food intake and energy homeostasis. Endocr Rev 2006; 27: 719-727.

130 Dakin CL, Gunn I, Small CJ, Edwards CM, Hay DL, Smith DM et al. Oxyntomodulin inhibits food intake in the rat. Endocrinology 2001; 142: 4244-4250.

131 Maida A, Lovshin JA, Baggio LL, Drucker DJ. The glucagon-like peptide-1 receptor agonist oxyntomodulin enhances beta-cell function but does not inhibit gastric emptying in mice. Endocrinology 2008; 149: 5670-5678.

132 Cohen MA, Ellis SM, Le Roux CW, Batterham RL, Park A, Patterson M et al. Oxyntomodulin suppresses appetite and reduces food intake in humans. $J$ Clin Endocrinol Metab 2003; 88: 4696-4701.

133 Baggio LL, Huang Q, Brown TJ, Drucker DJ. Oxyntomodulin and glucagon-like peptide-1 differentially regulate murine food intake and energy expenditure. Gastroenterology 2004; 127: 546-558.

This work is licensed under the Creative Commons AttributionNonCommercial-No Derivative Works 3.0 Unported License. To view a copy of this license, visit http://creativecommons.org/licenses/by-nc-nd/3.0/ 